\title{
Early Christianity: The beyond and its beliefs
}

Filipe de Oliveira Guimarães ${ }^{1}$

http://lattes.cnpq.br/3604539032125449

Enviado em: 30/08/2018

Aceito em: 22/09/2018

\begin{abstract}
This research seeks to examine, through an exegetical study in sacred book of Christians, the belief in the places of Beyond in Christianity in its beginning. Probably they believed that God had prepared places for God's creatures, whether human, fallen angels and nephilim. In order to acquire a more precise sense of these locations, this paper not only explores the meanings of key terms such as "Hell" and "Heaven" in their Greek forms, but also approaches the book of I Enoch to shed further light in this area. This research, which is exploratory and bibliographic, concludes that early Christians believed that there were five places besides the earthly dimension: three that coexist with the present reality and are temporary, and two eschatological destinations. ${ }^{2}$
\end{abstract} Keywords: Early Christianity, I Enoch, Heaven, Hell, Beliefs.

Resumo: Esta pesquisa procura examinar, através de um estudo exegético no livro sagrado do Cristianismo, a crença nos lugares do além professada pelos primeiros cristãos. Provavelmente acreditavam que Deus havia preparado lugares específicos para os seres humanos, anjos caídos e nefilins. A fim de adquirir um sentido mais preciso desses locais, este artigo não apenas explora os significados de termos-chave como "Inferno" e "Céu" em suas formas gregas, mas também aborda o livro de I Enoch para lançar mais luz sobre a temática. Esta pesquisa, que é exploratória e bibliográfica, conclui que os primeiros cristãos acreditavam que havia cinco lugares além da dimensão terrestre: três que coexistem com a realidade atual e são temporários, e dois destinos escatológicos. Palavras-chave: Cristianismo Primitivo, I Enoque, Céu, Inferno, Crenças.

\section{Introduction}

"That at the name of Jesus every knee should bow, in heaven and on earth and under the earth." (Philippians 2:10 - NIV)

The image this text evokes is the existence of different places, heavenly and earthly, which Christians believed in from the very beginning. The phrase "in heaven" invites us to think of paradise, peace, rest, a sweet place, harmony, and joy. The term "under the earth" brings to mind the place of shadows, pain, anguish, distress, darkness and hell.

One of the most enigmatic terms that appear in modern translations of the writings now contained in the New Testament (NT) is the word "hell," since this noun replaces three distinct Greek words that refer to different realms. This translation obscures the understanding of the thought of the New Testament writers who did not believe in only one place of punishment.

\footnotetext{
${ }^{1}$ Professor Dr. do Curso de Relações Internacionais da UNIFAP. E-mail: filipe.guimaraes@ufabc.edu.br

2 Este trabalho foi apresentado no Enoch Seminar, McGill University Canadá, com o financiamento da FAPESP e Enoch Seminar.
} 
The present paper aims to shed more light on the understanding of early Christians with regarding to their view of the beyond, which was very deeper. The key questions that guide this research are: What did early Christians believe about the fate of souls after death? What did they think about the eschatological destiny of human and spiritual creatures? What do early Christian texts tells us about Jesus' fate during the three days he was dead? In order to gain more precise answers to these questions, this research consults the book of 1 Enoch whose traditions were very influential to nascent Christianity.

\section{Places of Torment}

Von Allmen (2001, p.365) says that Hades in NT "is simply the gathering place of the deceased. However, for the bad it can become a place of torture." Buckland (2001, p.197), following this perspective, claims that the word Hades is the Greek form of the word Sheol and therefore means a "place where the souls of the dead go, without distinction of good and evil, happiness and suffering." For Rienecker (1995, p. 25), it refers to the "underworld, the realm of the dead". Stern shares a similar thought (1992, p. 69) when he states that "Hades is a vague place in which dead souls expect the trial." Reinforcing this team, Gingrich (1984, p.12) says it is "the underworld as the place of the dead."

What is similar among these ideas? Well, basically everything! The conceptualization is the same, with minor structured variations. All these authors define Hades as the destiny of all souls, whether good or bad. The problem is that such definitions do not apply to the New Testament. These concepts were borrowed from Greek mythology and used to define the Jewish mindset, causing obscurantism on the subject.

For the Greeks Hades was the homeland of the dead - whether good or bad - that was ruled by the god Hades (namesake). It was believed that the place was situated in the lower world, that is, below the surface of the earth. When someone died she or he was led by the emissary of the gods called Hermes to that place.

When we study the context of the passages in the NT where the word Hades appears, it seems that, in all cases, it is associated with punishment. All episodes contain a tone of threat against those who have not lived a righteous life. Below are texts where we find the word Hades in the KJV [2]:

- And thou, Capernaum, which art exalted unto heaven, shalt be brought down to bell (ä the mighty works, which have been done in thee, had been done in Sodom, it would have remained until this day. (Mat 11:23 KJV)

- And I say also unto thee, that thou art Peter, and upon this rock I will build my church; and the gates of hell (ö́dov) shall not prevail against it. (Mat 16:18 KJV)

- And thou, Capernaum, which art exalted to heaven, shalt be thrust down to hell (ö $\delta o u)$. (Luk 10:15 KJV)

- And in bell (ö $\delta \eta)$ he lifts up his eyes, being in torments, and seeth Abraham afar off, and Lazarus in his bosom. (Luk 16:23 KJV)

- Because thou wilt not leave my soul in hell (ö $\delta \eta v)$, neither wilt thou suffer thine Holy One to see corruption. (Act 2:27 KJV)

- He seeing this before spake of the resurrection of Christ, that his soul was not left in hell (ä $\delta \eta v)$, neither his flesh did see corruption. (Act 2:31 KJV)

- I am he that liveth, and was dead; and, behold, I am alive for evermore, Amen; and have the keys 


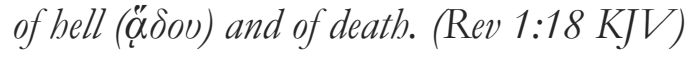

- And I looked, and behold a pale horse: and his name that sat on bim was Death, and Hell

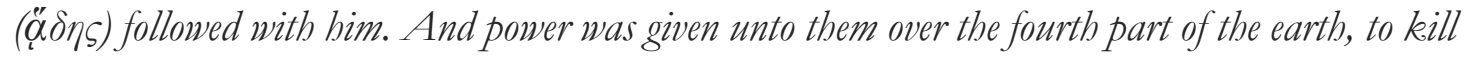
with sword, and with bunger, and with death, and with the beasts of the earth. (Rev 6:8 KJV)

- And death and hell (ö $\delta \eta \bar{\zeta})$ were cast into the lake of fire. This is the second death. (Rev 20:14 KJV)

In all nine cases in which the word Hades occurs in the New Testament the KJV translates it as Hell. In all cases, Hades is presented as a place of punishment, a place where people do not want to be. Another finding is that at no time does the word carry the idea

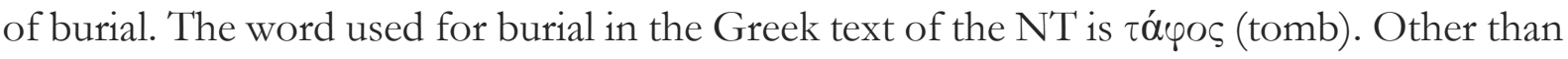

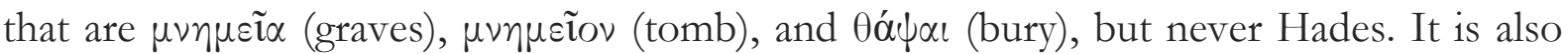
interesting to note that the words derived from Hades, which appear in the NT, such as $\dot{\alpha} \delta \eta \mu o v \tilde{\omega} \nu$ (distress), $\dot{\alpha} \delta \eta \dot{\eta} \lambda \omega \varsigma$ (uncertainty), $\dot{\alpha} \delta \eta \mu o v \varepsilon \tilde{v}$ (sorrowful) and $\alpha \delta \eta \mu o v \varepsilon \omega$ (be full of hate), have a negative meaning, always pointing to something bad.

A careful study of the word in its literary contexts reveals that "Hades" in the New Testament writings does not refer to a place in this world, but to realms belonging to the beyond. The writers of the New Testament believed it was the place reserved for the souls of the dead who did not live righteously before YHWH. This understanding can be seen in the episode of the rich man and Lazarus in Luke 16, where we find the word Hades referring to the place of torment for the rich man (Luke 16:23). Lazarus, however, went to Abraham's bosom, a place of joy, rest and delight.

Interpreting "Hades" as a dwelling of souls of the good and bad is a Greek idea also held by ancient Israelites that does not fully comply to the beliefs of certain Jews in the first century who viewed the beyond and afterlife along the lines found in the book of I Enoch. In the book of I Enoch we can find a text that point to this tradition:

Then I asked regarding all the hollow places, why they were separated one from the other. And he answered me and said, 'These three were made that the spirits of the dead might be separated. And this has been separated for the spirits of the righteous, where the bright fountain of water is. And this has been created for $<$ the spirits of the $>$ sinners... (I Enoch 22: 8-10) [3]

The concept of Hades in the Christian tradition, in its beginnings, was a place of punishment, preceding eternal damnation for those who lived far from God. In other words, Hades was a place of anguish for those who rebelled against the will of YHWH, a temporary place where their spirits would experience torments until the expected Day of Judgment.

The common Greek word for "death" in the New Testament is $\theta \alpha \nu \alpha$ qoc. In the book of Acts it occurs eight times, indicating that it was a favorite word of Luke. In Acts 2:27, Luke tells that Jesus went to Hades, which shows that early Christians believed that Jesus, as a substitute, would have known the place of torment for sinners.

Likewise, when Jesus says to Peter that the gates of hell (Hades) would not prevail on his church (Matt. 16:18), he is saying that his church would not go to that place. In other words, what Jesus said was: Hades will not receive the souls of his disciples. These words - the gates of hell will not have power over my church - were a great source of hope for early Christians, who believed that Jesus had the keys of Hades in his hands and never would open those doors for his people. "I am the Living One; I was dead, and now look, I am alive forever and ever! And I hold the keys of death and Hades." (Rev 1:18 NIV)

Another word that appears translated as hell in certain translations is "Gehenna" 
$(\gamma \varepsilon \dot{\varepsilon} \vee \nu \alpha)$. This word appears in the book of Matthew, Mark, Luke and James. In about $60 \%$ of cases it occurs in the book of Matthew and points to an eschatological place. Christians believed it was a place for creatures that are found guilty before God when they will be judged upon the return of Christ.

The basic differences in the primitive tradition between "Hades" and "Gehenna" concerns duration, status, and purpose. While the stay in Hades is of limited duration, from the death of a person who did not fear YHWH until the Day of Judgment, Gehenna is of eternal duration, starting after the trial and conviction of the culprits.

The second difference involves the state of the person: Hades is the space for the soul and Gehenna for soul in a bodily state (John 5:28-29). Regarding purpose, Hades is presented as the place of punishment for the souls of human beings, while Gehenna is perceived as punitive place for human, angels, and Nephilim (the sons of angles). Let us look at all the texts than human beings and disobedient spirits. We'll look at all the texts that speak of Gehenna in the NT:

- But I say unto you, that whosoever is angry with his brother without a cause shall be in danger of the judgment: and whosoever shall say to his brother,

- Raca, shall be in danger of the council: but whosoever shall say, Thou fool, shall be in danger of hell (jécvvav) fire. (Mat 5:22 KJV)

- And if thy right eye offend thee, pluck it out, and cast it from thee: for it is profitable for thee that one of thy members should perish, and not that thy whole body should be cast into hell (yécvvav). (Mat 5:29 KJV)

- And if thy right hand offend thee, cut it off, and cast it from thee: for it is profitable for thee that one of thy members should perish, and not that thy whole body should be cast into bell (yécvvav). (Mat 5:30 KJV)

- And fear not them which kill the body, but are not able to kill the soul: but rather fear him which is able to destroy both soul and body in hell (yécvvav). (Mat 10:28 KJV)

- And if thine eye offend thee, pluck it out, and cast it from thee: it is better for thee to enter into life with one eye, rather than having two eyes to be cast into hell (yécvvav) fire. (Mat 18:9 KJV)

- Woe unto you, scribes and Pharisees, hypocrites! For ye compass sea and land to make one proselyte, and when he is made, ye make him twofold more the child of hell (jeÉvons) than yourselves. (Mat 23:15 KJV) KJV)

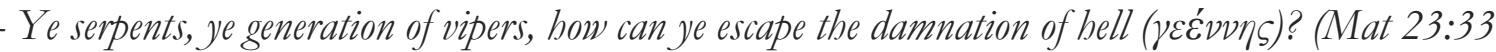

- And if thy hand offend thee, cut it off: it is better for thee to enter into life maimed, than having two hands to go into hell ( $\gamma$ Écvvav), into the fire that never shall be quenched. (Mar 9:43 KJV)

- And if thy foot offend thee, cut it off: it is better for thee to enter halt into life, than having two feet to be cast into hell (j'́cvvav), into the fire that never shall be quenched (Mar 9:45 KJV)

- And if thine eye offend thee, pluck it out: it is better for thee to enter into the kingdom of God with one eye, than having two eyes to be cast into hell ( $\gamma$ Écvvav) fire: (Mar 9:47 KJV)

- But I will forewarn you whom ye shall fear: Fear him, which after he hath killed hath power to cast

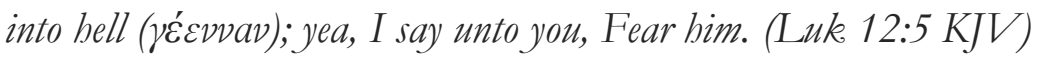

- And the tongue is a fire, a world of iniquity: so is the tongue among our members, that it defileth the

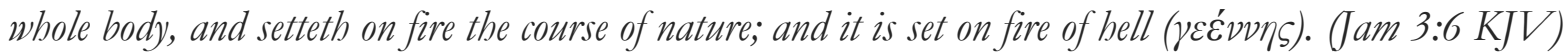

The word Gehenna appears twelve times in the New Testament. It generally speaks of "the body being thrown into hell (Gehenna)", "to destroy the body" and "coming doom." 
We note that it is also associated with unquenchable fire (Mark 9.43). Taking these considerations we deduce that the term "lake of fire" and "second death" occurring in Revelation 20:14 refer to Gehenna. The same applies to the expression "eternal fire" that occurs in Matthew 25:41.

2 Pe 2.4 contains a singular word: "For if God spared not the angels that sinned, but cast them down to hell ( $\tau \alpha \varrho \tau \alpha \varrho \omega ́ \sigma \alpha \varsigma)$, and delivered them into chains of darkness, to be reserved unto judgment." (KJV)

Why did Peter use the word Tartarus and not Hades or Gehenna? The answer is provided by the context of the narrative itself: the author did not have in mind a place of torment for humans, nor was he speaking of the final judgment (i.e., Gehenna). He meant to describe a place of torment for angels. For ancient Jews, based on the book of I Enoch, this realm was reserved for angels.

It appears that the letter of 2 Peter refer to the place of torment for the Watchers who according to the book of I Enoch were "sons of God", that is, angels who disobeyed divine orders by cohabiting with women and having children (Nephilim or giants). Early Christians believed that punishment for these angels would have been imprisonment in Tartarus where they would wait for the Day of Judgment and condemnation when they would be cast into Gehenna. (Mt 25:41)

The word Tartarus used in 2 Peter is the same word that appears in the book of I Enoch 20.2. This passage claims that the angel Uriel is responsible for guarding this place: "These are the names of the holy angels who watch. Uriel, one of the holy angels, who is in charge of the world and over Tartarus."

Peter believed that Jesus visited this place and its inhabitants:

For Christ also hath once suffered for sins, the just for the unjust, that he might bring us to God, being put to death in the flesh, but quickened by the Spirit: By which also he went and preached unto the spirits $(\pi v \varepsilon v ́ \mu \alpha \sigma \iota v)$ in prison Which sometime were disobedient, when once the longsuffering of God waited in the days of Noah, while the ark was a preparing, wherein few, that is, eight souls were saved by water. (1Pe 3:18-20 KJV)

It is important to remember that the word spirits $(\pi v \varepsilon v ́ \mu \alpha \tau \alpha)$ also occurs in the New Testament in reference to angels, whether good or bad. For example, Hebrews 1:14 states: "Are they not all ministering spirits, sent to service?" Other examples include 1 Tim 4:1; Rev. 16.13-14; Acts 19.12,13.

It is likely that Peter is alluding to watchers who were imprisoned in Tartarus, which was believed to be a place of darkness and total isolation. But what about the belief in Jesus' visit to preach to the spirits in Tartarus? The answer is that Peter was not referring to a type of preaching of salvation or consolation to these spirits, because, according to I Enoch 10:12-13, these Watchers were eternally condemned.

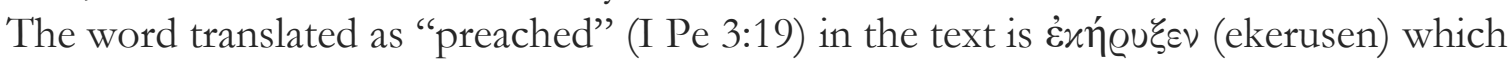
means to proclaim. In this sense, the idea that Peter wants to convey for Christians at that time is that Jesus went to Tartarus to announce: "It is finished" (John 19:30). In other words, the author could be saying that Jesus' victory was known in all the inhabited places: in the sky, on the earth, in Hades, and Tartarus.

There is a word that can be used as a synonym of Tartarus and Hades in the NT. That

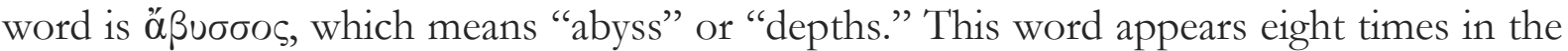
New Testament. It can be used to replace either Hades or Tartarus, since some ancient Jews perceived both places as lying somewhere in the depths.

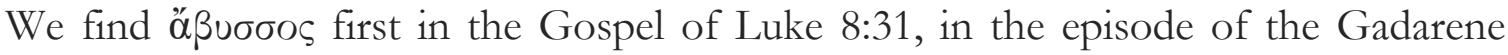


demoniac. In that text it is used as a synonym for Tartarus. In the narrative the evil spirits begged Jesus not to send them into the abyss. And why does Luke say that they did not want to go there? Because early Christians, like some Jews, believed that the abyss, either as reference to Hades or Tartarus, was a place of torment. It is interesting that Luke presents Jesus as someone who had authority over the regions of the deep, and could send demons there.

The only place abyss appears as a synonym for Hades is in Romans 10:7. The text says: "Or, Who shall descend into the deep? That is, to bring up Christ again from the dead." $(\mathrm{KJV})$ In this text we realize that it appears as a replacement for Hades. Paul contrasts this descent with the ascension of Jesus to heaven (Romans 10:6); probably wanting to communicate that Jesus encountered Hades and returned there, suggesting the idea that he overcame Hades.

Finally, the Greek word for abyss appears six times in the book of Revelation (Rev. 9:1, 9:2, 9:11, 11:7, 17:8, 20:1). Whenever it occurs there, it refers to the place where the "beast", "satan", non-human creatures as such as the "angel of the abyss" is or will be released. In all these cases it is similar to Tartarus.

\section{Delights' Places}

The NT refers to anotherintermediate space reserved for the righteous. It is a place of joy, peace, and rest for the souls of the servants of YHWH rest while awaiting trial to receive their reward and a glorified body, to then enjoy, holistically the benefits that YHWH has reserved for them for all eternity.

This place is listed in Luke as "Abraham's bosom" (Luke 16:22) - the place that the beggar moved to after his death. Apparently the Gospel of Luke presents it as if it were a place one can also contemplate God, and the angels. It is not the "New Heavens and New Earth", but a kind of anteroom of heaven.

The book of Revelation presents the souls of those who were slain for the gospel crying out for justice, but they are told to rest a little longer (Rev. 6:9-11). The Pauline expression "having a desire to depart, and to be with Christ; which is far better" (Phi 1:23 - KJV), is an indication of his belief in the existence of this place.

Another term in the NT this is "New Heavens and New Earth." This term is usually interpreted as the eschatological place reserved for the servants of YHWH who, with a glorified body, similar to angels, will enjoy the fullness of divine blessings.

In the book of Revelation this place is also called the "New Jerusalem coming down from heaven," and is presented as a place where there will be no tears, death, mourning, crying, pain, or curse, for the former things will have passed away. The place where YHWH will make all things new and where people can contemplate God's face. (Rev. 21-22)

Another expression used by Jesus to describe this place, according to the gospel of Matthew, is "my Father's house." The narrative in Matthew indicates that God's people will be welcomed by Jesus himself to enjoy this place: "Then Shall the King say unto them on his right hand, come, ye blessed of my Father, inherit the kingdom prepared for you from the foundation of the world" (Mat 25.34 - KJV)

A challenging passage appears in Luke 23:43. The text recounts a conversation that Jesus had with the repenting thief during his crucifixion: "And Jesus said unto him, verily I say unto thee, Today shalt thou be with me in paradise" (Luk 23:43 - KJV). What is this paradise? Is it a reference to the middle place (e.g. Abraham's bosom) or an eschatological 
place (i.e., the New Jerusalem)? According to certain modern translations Jesus was apparently telling the thief that he would be with him that day in paradise. In this case Jesus would be referring to an intermediate state.

By punctuating the text differently (the ancient Greek texts, as is known, did not contain punctuation marks), we can understand the passage differently. Placing after the word "today" a comma rather than before it alters the meaning of the passage significantly. In this case the translation would be: "And Jesus said unto him, verily I say unto thee today, shalt thou be with me in paradise". This small change alters the entire meaning of the sentence giving the idea that "paradise" is an eschatological place.

In this case "paradise" signifies the abode of the righteous after the final judgment. The book of Revelation reinforces this interpretation when interpreting paradise as an eschatological place: "To him that overcometh will I give to eat of the tree of life, which is in the midst of the paradise of God." (Rev 2:7 KJV). When Paul says that visited the third heaven (he calls paradise) is speaking of an eschatological place (2Co 12:2-4 ARA).

But the text that leads us to conclude that Jesus was speaking of an eschatological paradise to the thief is John 20:17. In this text Jesus said he had not yet gone to the Father's presence: Jesus said: "Do not hold on to me, for I have not yet ascended to the Father"

\section{Conclusion}

This research sought to assess, through the study of words within their respective literary contexts and through an analysis of the Book of Enoch, the beliefs of early Christians about the places of beyond. The conclusion we reached is that the early Christians believed that there were five places apart besides earth reserved for humans and spiritual creatures. Three places coexist with the present reality and are, temporary nature, while two are eschatological and eternal.

The temporary realms are: Hades (an intermediate place of torment for the souls of the wicked), Abraham's Bosom (an intermediate resting place for the souls of the servants of God); Tartarus (an intermediate place of torment for non-human creatures). The eternal reals are: Gehenna (an eschatological place reserved for convicted creatures, whether human or non-human), the New Heavens and New Earth (an eschatological place reserved for, obedient angelic creatures, and righteous).

The investigation also concluded that Christians who lived in the first century and second centuries of the Christian era believed that Jesus went to two places during the three days of his death, which are: Tartarus: a place where Jesus declared his victory to the imprisoned angels and Hades: a place of punishment for those who were not servants of God.

\section{References}

BUCKLAND. A. R. Dicionário Bíblico Universal. São Paulo: Editora Vida. 1981; GINGRICH. F. Wilbur. Léxico do N.T Grego/Português. São Paulo: Vida Nova. 1984; NICKELSBURG, G. W. E. and VANDERKAM, J. C. I Enoque: a new translation. Fortress Press, 2004.

RIENECKER, Fritz. Chave lingüística do novo testamento. São Paulo: Vida Nova. 1995; STERN. David H. Comentário judaico do Novo Testamento. São Paulo: Editora Atos. 2008

VON ALLMEN. J. J. Vocabulário Bíblico. São Paulo: Aste 2001; 
[1] Researcher Dr. Collaborator at UFABC in International Relations.

[2] In this article we use the KJV because it represents well the translations made until the early twentieth century. It was common for translations to use the word "Hell" to replace "Hades", "Gehenna" and "Tartarus". With the arrival of newer translations (RSV, NIV, etc.) this paradigm began to be broken because the versions would retain the word "Hades" in certain passages, but continued translating "Gehenna" and "Tartarus" as "Hell", obscuring the meaning of the text. The same occurs with the NRSV. The fact remains that even with the newer translations this issue requires clarification.

[3] Nickelsburg, G. W. E. and Vanderkam J. C. translation. 2004. 